\title{
Breaking News; the Naira goes to the moon: The intriguing story of corruption in Nigeria.
}

\author{
Danazumi Bukar
}

\begin{abstract}
The story of corruption in Nigeria has an appalling profile. Corruption has eaten deep into our national fabric to the extent that it has involuted the machinery of the state. This accounts for the abysmal proportions of the country's corruption saga. Thus the state apparatus is being used for primitive accumulation by those who control it instead of using it to build our national economy for the benefit of the citizens of the country.

It is also this fact that is accountable for the intractability of corruption in the country and its pervasiveness. It will therefore require a huge political action to deal with the ugly situation.
\end{abstract}

Key words: corruption, involution, institutionalization, state intriguing.

\section{Introduction}

Corruption in Nigeria is intrinsically organic in nature which gives it the growth potential it has brazenly exhibited over the years of our cheaqured history as a country. Thus for this paper, it is this growth potential that is of interest. Anybody looking at the country's profile of corruption might likely miss his step while confronting the brand of corruption the country has domesticated. Corruption in Nigeria is not only progressive but also involuting. Why has it for example grown from the realm of a mundane social aberration to a full grown institution? The answer lies in the politicization of corruption. We shall therefore look at how the political process in Nigeria came to nurture corruption, instead of genuine development, which has in turn cut a character an identity of its own.

\section{The Roots}

The seeds of corruption in Nigeria were indeed well sown. Colonialism was the seed time of this malaise for its concomitant political economy configuration was not a maturation of the pre-colonial states in the country, but the imposition of a power superstructure over a hitherto independent array of states. This was a major act of corruption in which these states that became Nigeria were twisted or better to say, $\operatorname{corrupted}^{1}$ to serve the interest of a new order.

In this regard, the indirect rule system was a huge process of corrupting the structures of these precolonial societies to serve a different purpose, other than those they were doing before. Thus so long as the colonial state lasted, the peoples and the structures of their societies continued only as a corruption of their former essence no longer serving their true and long term interests. These true interests of the people were considered to be a burden which at this point in our history has been exhaustively researched into. However in tracing the roots of corruption in the country, it is necessary to look at not only the roles played by the colonialists but more so those played by Nigerians who collaborated with them.

Using the tools of the carrot and stick, the colonial state domesticated a class of collaborators beginning with the pre-colonial rulers of the people known in common parlance as traditional rulers and then the educated elite. This was done using whatever means it took in order to access and control first the labour of the working classes and ultimately the surplus they produced.

The growing needs of the Colonial State and international pressure such as the Phelps Stokes commission $^{2}$, began to force the colonialists to give some form of education especially from the 1920 s which in addition to the efforts of the Christian Missionaries in this field, produced the educated elite that was groomed alongside the traditional rulers to hand over power to. This class as a group and section of the Nigerian society was the most refracted and twisted ${ }^{3}$ by the colonial state as they groomed it to serve their interest.

This was the class that power was handed over to at independence as a form of a corrupted entity in the sense that its primary pre-occupation ${ }^{4}$ was the service of imperialism to which we now turn our attention.

\section{A Corrupted ${ }^{5}$ Ruling Class.}

The peaceful and non violent process of transfer of power to the nationalist class, heroic as it appeared, was symptomatic of two fundamental flaws in the essence of this class. Firstly, it proved that they were basically subservient in nature having passed the training given them by the colonial masters. Secondly, it showed that the class was entrapped in the world outlook of their over-lords, having failed to break out of it. 
Thus, they did not contemplate nor attempt to explore other options to the terms of independence leaving us with the neo-colonial framework of the state bequeathed to us at independence. The meaning of this, at a more disturbing level before independence was granted, was the assurances this class exuded of not tampering with the neo-colonial nature of the state. They proved this subsequently, lacking the courage and commitment to do otherwise. ${ }^{6}$

We may consider this to be the birth place of the poverty of leadership in this country, the worst thing being the inability of this class to shrug off this toga of dependence and reliance on development ideas from the west. They have flirted with such ideas as the bogey of import substitution or the development plans, the Structural Adjustment strategy and its Privatization ambit, being ideas promoted by the IMF and the World Bank. Following their ideas have been like chasing the wind that has left us deeper in the trenches of imperialism with the latest whirlwind of globalization which is a form of capitalism without borders. ${ }^{7}$

At independence this class probably did not realize that power can only be exercised for and on behalf of some body. Who that somebody was, they did not clearly reckon with .We must however realize the fact that up to this point, they were probationary in nature. We say this because we should not blame them for their grooming as protégés of the colonial overlords. Nevertheless, this was a significant junction of our national history-which this class presided over. Their world outlook, ideology, preferences, choices and failures would definitely have resounding impacts on what becomes of the country, being the watershed of our nationhood.

We would not however forgive these nationalists for their inability to re-determine and redefine the leadership roles and styles they were cut out to play by the colonialists. Instead of loathing this, they relished in it, failing woefully to comprehend intrinsic shortcomings of their composition and constitution as a watershed (ruling class) at a critical historical juncture. They could not see how by their nature, they could only operate more or less as puppets, satraps and officials of another country. By this, they could, more seriously, not understand the contradictions they were saddled to manage, let alone do something about it. ${ }^{8}$

Since this leadership class derived its power not from the Nigerian people, it was not difficult for them not to have any debt of commitment to them, let alone make the choice of serving their truest interest which was diametrically opposed to that of imperialism. Thus for Nigeria to have been saddled with a ruling class that lacked the ideology of self-determination for itself and its people and a clearly defined charter of reconstructing a country coming out of sixty years of colonial domination and ruination, was a great tragedy. The class was simply ill-equipped to confront and manage the challenges of this burden of history. ${ }^{9}$ we must however, all the same, acknowledge the efforts of the Nationalists in fighting for our independence even though they failed to first seek to decolonize the process especially their minds and thinking. They did not seek to decolonize the deeper cultural undertones of the capitalists' ethos which accounts for our transition into neo-colonialism and which also implicitly provided the raw platform for the corruption that is ruining the country.

\section{Corruption as a Process of Capital Accumulation.}

We need not belabor the fact that colonialism was self-serving in all that it did in the name of development. All was geared towards creating the country as a back water of the capitalist system-or a dependency even though a much greater dependency was the lumpen bourgeoisie that this system created. For the capitalist economy of the country that developed from the colonial economy was only a mock replica of metropolitan capitalism hence the lumpen nature of the Nigerian bourgeoisie.

This remains a major feature of the Nigerian story i.e. the fact that at independence it was left with an economy that was miserable back water and a class of economic managers that were bereft of the thrift, drive and patriotism required of such a class. This was not all. They had no capital base with which to create an autonomous private sector as only foreign businesses dominated the economic space created by the colonialism using the might of the state.

Nevertheless, these classes of Nigerians were handed over the massive powers of the state created by the colonialists for the purpose of exploitation. The state was used by the colonialists for both capital accumulation and capital flight which is the primordial stage of corruption in the country. This argument is predicated on the fact that capital flight in any national economy is primarily a process of under developing that economy as it is usually from resources like these that reinvestment in an economy is made to push for its further development. Therefore it was a twist of bad destiny for Nigeria when its ruling class since independence, given the low profile of capital at their disposal began to, as their over lords did before them, use the state for private capital accumulation. This discredited and reactionary use of the state has continued as a bane of the development of the country. There are four basic characteristics of this process of abuse of state powers. The state is used:

1.1 To create a conducive environment for transnational investment to thrive as against the indigenous economy.

1.2 To corner, divert and embezzle government resources. 
1.3 To promote personal aggrandizement in the form of kick backs, bribes thereby allowing shoddiness in the execution of government business.

1.4 To protect sectarian, personal and selfish interests thus attenuating the process of the rule of law, human, minority and gender rights.

\section{Institutionalization of Corruption.}

It is in this context that corruption in Nigeria has been unfolding under the patronage of the state. The very nature of the Nigerian state and the way it is operated provided ample reins for corruption to thrive in the conduct of both government and private business.

The point to note categorically is the fact that corruption is not lacking in all countries of the world. But like cancer, if it is detected early enough, it could be excised and gotten rid of before it spreads to the destruction of the victim. If not, it becomes in that case a festering organism that eats into the very sensitive parts of the host destroying them. We have already alluded to the fact that corruption in Nigeria is like a living organism. The Nigerian ruling class has not tackled this problem but has rather allowed it to smolder from a little speck to a bone fire setting ablaze the entire fabric of the society. Thus although no society can be said to be pristinely corruption free, one way or the other, many societies have not allowed it to acquire the characteristics of a living organism. In these societies the ugly face of corruption is roundly considered as a rude embarrassments and its practioners easily identified, exposed and brought to justice in the public eye of these societies that are non tolerant and watchful so as to stem the spread of such action.

From what we have said so far, it is clear that the Nigerian state was created by the colonialists for the wrong reasons, i.e. to loot the resources of the state. The Nigerian ruling class did not clearly deal with this problem when they simply negotiated for a neo-colony. The state has therefore continued to exist for the wrong reasons hence the crises that have been assailing it. The country nearly disremembered during the first republic which ushered the military into power. The military also failed to correct this abnormality. In fact they worsened the situation because they militarized the Nigerian psyche and conduct of government business. They increased the powers of the state and its propensity for corruption. ${ }^{10}$ No wonder episodes such as the loss of 2.8 billion naira, the Bus Scania scandal, the Cement Armada, and the gory pictures of the Abacha loot put at about 2\% of the country's GDP.

As a result, corruption as repeatedly said, spread to all the fabric of the society. With a free rein to flourish, corruption in Nigeria has stealthily progressed to become an institution. We are therefore no longer dealing with individualized but institutional corruption arising from the very nature of the Nigerian state.

Nigeria is now dealing with a huge internal monster of corruption that has generated a process of involution taking over its organs. In fact we can now say that this process has created internal colonies for its practioners who milk government departments and organs. Or how do we look at the third tier of government, aptly described as sharing centres. How also do we look at state governors, who have become tin gods managing state resources with their cronies as they please. With episodes of corruption in our recent history such as the scam in the Power Sector, Oil subsidy, and the Pension Scheme, is it then surprising that Nigerians are scorned and snubbed in the international environment as not trustworthy? What else should we expect given the fact that nearly all institutions in the country have been skewed in favour of corrupt practices, putting us as the third most corrupt country in the world?

\section{How Much Has Been Stolen?}

The story of corruption in Nigeria as discussed in this paper will not be complete without giving a glimpse into the quantitative side of this story. Arriving at a specific figure may not be easy. We however got a figure. According to Antonio Maria Costa, Executive Director UNODC, the amount of money stolen from public coffers in the country since independence is put at $\$ 400$ billion, saying that if you put this in a row, it would make a path way to the moon and back 75 times. The fact that the amount of money involved in worldwide bribery on annual basis is about 1 trillion dollars, makes the magnitude of corruption in Nigeria quite frightening and intriguing.

\section{Tackling Corruption in Nigeria}

With this magnitude of corruption in Nigeria, it would be surprising if no political will had in the past been mustered to deal with it. Four serious attempts are, in this regard, discernible, which include the vigorous and rapacious campaigns mounted by the General Murtala Mohammed's military regime between 1975 and 1976. The then head of state began with himself giving up houses to the Kano State Government which he felt he could $\mathrm{d}$ not keep in good conscience. The campaigns were almost a kind of political inquisition in which the low and mighty were affected, taking heavy tolls on them. The next campaign was mounted by the General Muhammadu Buhari's administration between 1983 and 1984. This one like the one before it was equally inquisitous involving mainly politicians that had looted government funds during the second Republic between 
1979 and 1983. The campaign particularly targeted the "NPN crowd" that was in power during this period which the failed attempt to deport Umaru Dikko, regarded as the king pin of the episode of corruption the government perpetrated, epitomize. Like Murtala Mohammed, Buhari's regime was both characterized by unprecedented brevity which prevented their campaigns from developing a rhythm and permanence.

General Babangida who toppled the Government of Buhari put up a different approach from the previous two before him. He avoided the path of inquisition these two took and attempted to wage a moral and ethical war against corruption. The cliché War Against indiscipline was adopted to catch the spirit of the campaign which actually amounted to only a mockery of the huge monster of corruption in the country which unfortunately enjoyed an unjustified longevity - 1985- 1993.

The Police, in the interim, created a case file, 419 , to deal with the obnoxious crime of advanced fee fraud in the country on the heels of which the Obasanjo administration introduced his own version of the war against corruption which came under the general description of economic and financial crimes. This effort was beset by the third term bid, the power sector scam and the privatization scandals that largely surfaced after the end of the administration. As a matter of fact, it was believed that the Economic and Financial Crimes Commission (EFCC) was largely put in place only meant to witch- hunt political opponents.

The emerging reality in this discussion is the fact that corruption in the country can only be solved from its roots which are in the state itself. So far it is the managers of the State that have been attempting to deal with the problem to no avail.

\section{References}

[1]. The concept used here considers colonialism not only from the usual naked violence and violations it carried but also the subtle distortions it introduced that are today more difficult to rid the country of such as the crass exhibition of lack of accountability shown by the ruling elite.

[2]. For a picture of what this commission did, see A. History Fafunwa, B.of Education in Nigeria, London 1975 PP 119- 123, 125; 197198.

[3]. The educated elite were a creation of colonialism hence their susceptibility to this process especially when compared to the peasantry whose linkages with the colonial state was vicarious.

[4]. This view of the Nigerian ruling class may appear too extreme but it is based on their antecedents since independence.

[5]. This label is predicated on the fact that this class was not able to cure itself of their shortcomings and contradictions.

[6]. This intrinsic poverty is responsible for the general deterioration in the quality of life in Africa. See Bokelmann, O; Akinwumi, UM; Agwuele, A. D eds, African leadership challenges and other issues, 2012.

[7]. Professor Elaigwu, J. I recently dwelled extensively on this futility of development using "western models of nation- building".

[8]. It is not surprising that this class failed to keep the ship of state a float as the country sunk into the abyss of a three year civil war between 1967 and 1970 .

[9]. See 8 above

[10]. One very clear development in this regard was the centralization of power in the country. See Elaigwu, J. I The challenges of Nation Building in the Twenty-first century, the Nigerian Experience 2004.

[11]. Anti corruption climate change in Nigeria. Nigeria corruption busters speech by Autonia Maria Costa, Executive Director UNODC. Downloaded 7/9/2010. 